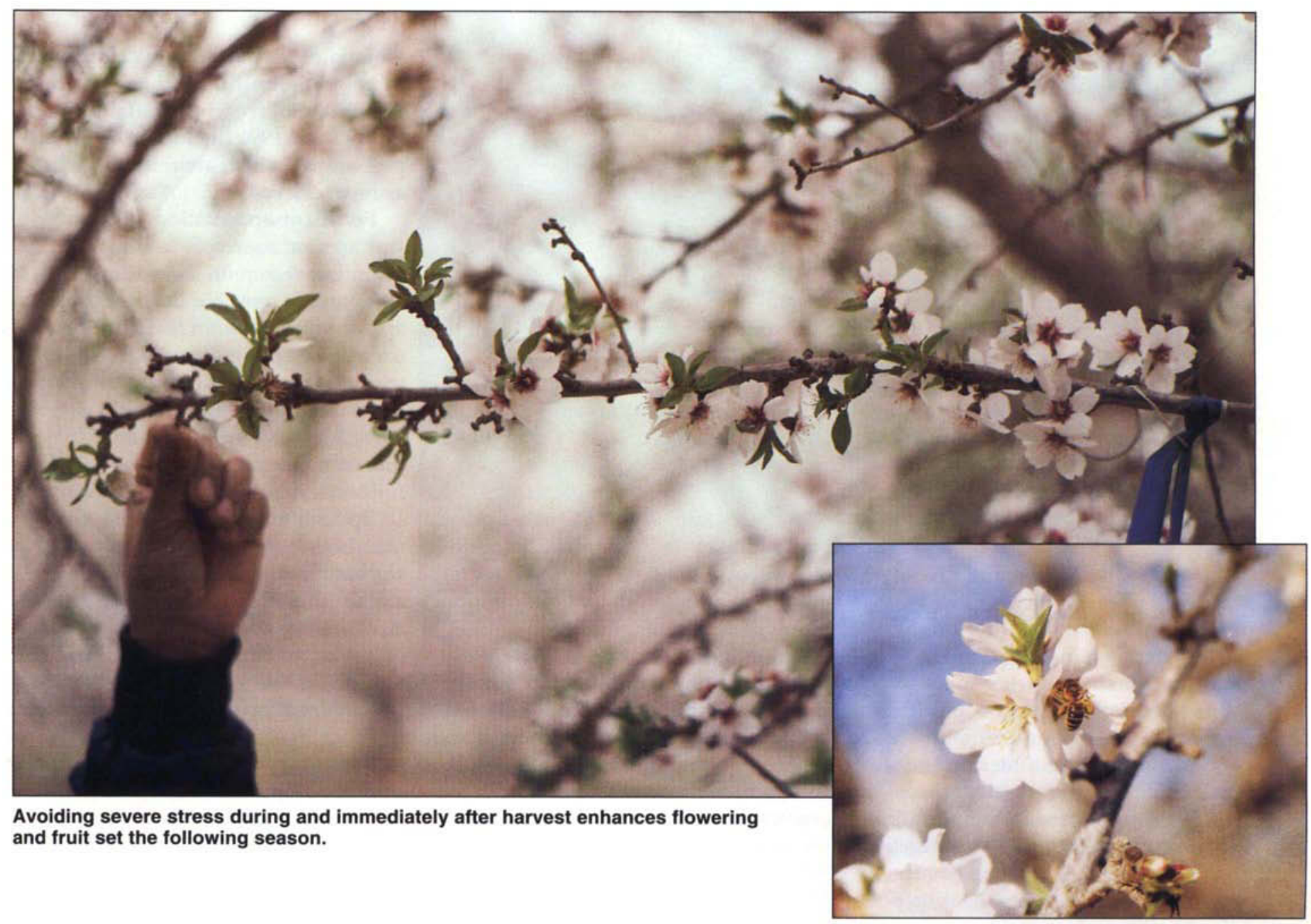

\begin{abstract}
Yields from five irrigation regimes that each applied 16 acre-inches/ acre were evaluated during a simulated drought year and for the subsequent two seasons under full irrigation. Drought-year production was mildly reduced by regimes that produced smaller kernels. Much greater losses occurred in the season immediately following the drought due to reduced nut load. Applying a limited allotment of water early in the drought season proved less effective in limiting subsequent production losses than irrigating at a lower rate but for a longer period of the drought season. Avoiding severe water stress during flower bud development (August and September) is critical for subsequent bloom and fruit set.
\end{abstract}

\title{
Single-season drought irrigation strategies influence almond production
}

\author{
David A. Goldhamer D Timothy E. Smith
}

A mature almond orchard in the interior valleys of California can use 36 to 38 acre-inches/acre (hereafter referred to as inches) of water in an average weather year. During periods of drought, growers with wells can continue to pump groundwater to meet their irrigation needs, but growers serviced by irrigation districts may have their normal allocations reduced.

Moreover, escalating competition from the municipal and environmental sec- tors has added pressure on what is essentially a fixed surface water supply. Whether tight water supplies are due to droughts or increased competition, many almond growers will periodically have to decide how best to manage smaller amounts of water than they normally use. Since there are about 400,000 acres of bearing almond orchards in California, the economic impact of poor drought-year water management is potentially severe. 
When water supplies are not restricted, irrigations are generally scheduled to meet the full water needs of the trees and to prevent tree water stress. With limited water, it is a question not of whether the trees will be stressed but of when the stress will occur. Growers facing severe irrigation cutbacks must decide the best time to apply water in terms of short-term and long-term orchard productivity. While one strategy may be best for maximizing nut yield and quality during the drought year, using that strategy may drastically reduce future production.

Knowledge of when important tree and fruit developmental processes such as shoot and spur growth, fruit growth, hull split and reproductive bud development - occur and the sensitivity of each process to water deprivation is essential for drought irrigation decision making. For example, water stress during some stages of bud development can affect flower density (the number of flowers per tree) and fruit set (the number of flowers that evolve into fruit) in following years. Reduced shoot growth will not have an immediate ramification on production, but may eventually reduce the number of fruiting positions and therefore yield.

A 3-year study was conducted to assess yield responses of 'Nonpareil' almonds to four deficit irrigation regimes under a 1-year simulated drought in 1989. The trees were returned to full irrigation in the following two seasons (1990 and 1991), and monitoring continued to determine tree recovery from the single drought year.

\section{Experimental design}

In 1989, mature 'Nonpareil' almond trees on a deep, fine sandy loam soil near Fresno were irrigated with five treatments, four representing different drought irrigation strategies that applied the same seasonal amount of water and one acting as a fully irrigated control. The drought strategy treatments each applied a total of 16 inches, which was the amount of water that the Westlands Water District anticipated delivering to growers in 1989. The plots were laid out in a ran-
TABLE 1. Irrigation regimes imposed in 1989

\begin{tabular}{|c|c|}
\hline Treatment & Treatment description \\
\hline $1(\mathrm{~T} 1)$ & $\begin{array}{l}100 \% \text { of the crop water requirement } \\
\text { (ETc) for the entire season }\end{array}$ \\
\hline $2(\mathrm{~T} 2)$ & $100 \%$ of ETC up to 16 inches total \\
\hline 3 (T3) & $75 \%$ of ETc up to 16 inches total \\
\hline 4 (T4) & $50 \%$ of ETc up to 16 inches total \\
\hline 5 (T5) & $\begin{array}{l}\text { Variable ETc percentage applied up to } \\
16 \text { inches total: } \\
\qquad \begin{array}{l}80 \% \text { ETc through mid-May } \\
60 \% \text { ETc through mid-June } \\
40 \% \text { ETc through early July } \\
60 \% \text { ETc until harvest. }\end{array}\end{array}$ \\
\hline
\end{tabular}

domized complete block design, with each treatment replicated four times.

Each plot consisted of three tree rows: a center harvest row of 'Nonpareil' trees bordered by a 'Nonpareil' buffer row on one side and a 'Carmel' buffer row on the other. Each plot contained 18 trees under drip irrigation. Harvest data were taken from the four interior trees of each center row.

Irrigation management. The 1989 treatment designations and irrigation regimes are shown in table 1 . Drip irrigation was used and the various percentages of evapotranspiration (ETc) were accomplished using different emitter discharge rates and numbers per tree. Applied water was measured with water meters. The irrigation cutoff period prior to harvest averaged 7 days for the duration of the study.

All plots were irrigated with 4.2 inches in January 1989 to ensure an initially full soil moisture profile. Seasonal irrigation began in March 1989. Irrigation scheduling was based on reference crop water use (ETo) obtained from a nearby California Irrigation Management Information System (CIMIS) weather station and published almond crop coefficients (Kc's). Table 2 shows monthly irrigation amounts in 1989. All plots received full irrigation in 1990 and 1991 (including 4.2 inches preseason), which are referred to here as recovery years.

Fertilizer application. Nitrogen was applied twice per season: 150 pounds per acre in the spring and 100 pounds per acre in the fall. Both applications were in the form of urea-ammonium solution. The fertilizer was applied by hand during 1989 and through the drip system in the subsequent seasons. A foliar zinc application was applied in the spring at full leaf extension.

Soil water measurements. Soil moisture content was determined biweekly through harvest in 1989 using a neutron probe calibrated for the site. Access tubes were installed 5 feet deep on the shoulder of the wetted surface area on each of two replications per treatment. Measurements were made in 1-foot increments.

Harvest procedure. The trees were mechanically shaken and nuts allowed to dry on the orchard floor for 4 days. Nuts from the four monitored trees per plot were then hand raked and weighed.

Nut subsamples ( 4 to 5 pounds each) were collected from each plot and characterized based on the degree of hull split as follows: full (greater than half the suture open), partial (less than half the suture open) and hull tight (suture unsplit). Hull, shell and kernel weights were also determined. The number of almonds per tree was calculated by dividing the harvested
TABLE 2. Simulated drought year (1989) monthly irrigation amounts during the season and calculated almond ETc

\begin{tabular}{|c|c|c|c|c|c|c|}
\hline \multirow[t]{2}{*}{ Month } & \multicolumn{5}{|c|}{ Treatment } & \multirow{2}{*}{$\begin{array}{c}\text { Almond } \\
\text { ETc }\end{array}$} \\
\hline & T1 & $\mathrm{T} 2$ & T3 & T4 & T5 & \\
\hline \multicolumn{7}{|c|}{ 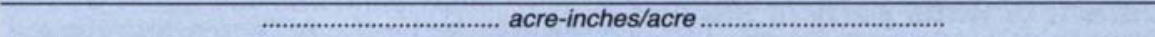 } \\
\hline March & 0.9 & 0.9 & 0.6 & 0.4 & 0.9 & 1.9 \\
\hline April & 4.7 & 4.6 & 3.3 & 2.3 & 3.6 & 3.1 \\
\hline May & 6.2 & 6.2 & 4.4 & 3.1 & 4.3 & 5.0 \\
\hline June & 7.8 & 4.4 & 5.7 & 4.2 & 4.1 & 6.5 \\
\hline July & 8.7 & - & 2.2 & 5.5 & 3.1 & 8.4 \\
\hline August & 5.5 & - & - & 0.8 & - & 5.1 \\
\hline September & 5.4 & - & - & - & - & 3.7 \\
\hline October & 3.2 & - & - & - & - & 1.5 \\
\hline November & 2.1 & - & - & - & - & 0.8 \\
\hline Total* & 44.5 & 16.1 & 16.2 & 16.3 & 16.0 & 36.0 \\
\hline
\end{tabular}


field weights by the average nut weights in the subsamples.

\section{Drought season (1989)}

Soil moisture early in the season (April 15) in the top 3 feet of the profile reflected the different irrigation rates (fig. 1). The $50 \%$ irrigation rate (T4) averaged about 1.0 inch of water per foot of soil, the $75 \%$ rate (T3) averaged about 1.75 inches of water per foot of soil and the fully irrigated treatments ( $\mathrm{T} 1$ and $\mathrm{T} 2$ ) averaged about 2.5 inches of water per foot of soil. As the season progressed and the higher irrigation rate regimes exhausted their seasonal allotment of 16.0 inches and were shut off, soil water was rapidly depleted in these treatments. By July 28 , soil moisture was directly related to the date of irrigation cutoff (fig. 2). For example, T2 (June 19 irrigation cutoff) and T4 (still irrigating) had average soil water contents of about 0.6 and 0.85 inches of water per foot of soil in the top 5 feet of the profile, respectively. The control (T1) averaged about 1.25 inches of water per foot of soil on the same date. Although we took no direct measurements of tree "stress," plant water status often mirrors soil moisture levels, since these

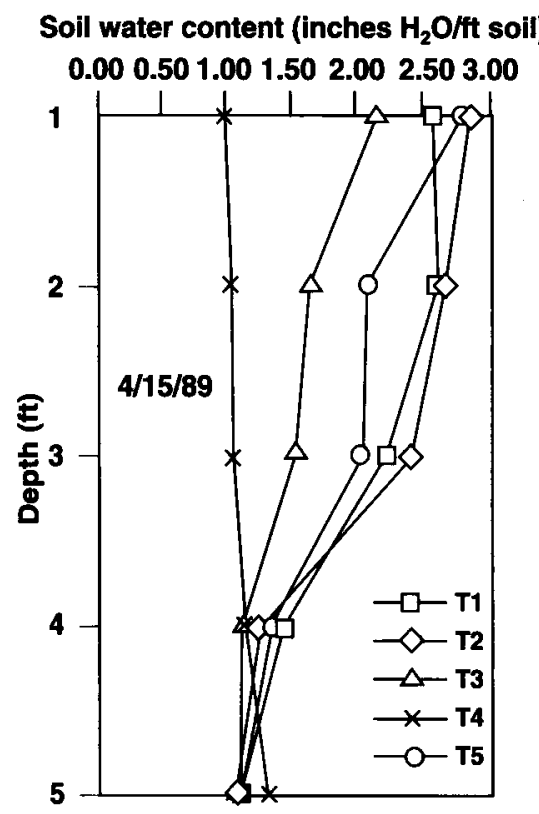

Fig. 1. Distribution of soil moisture measured early in the 1989 season prior to atlotment usage in any treatment.

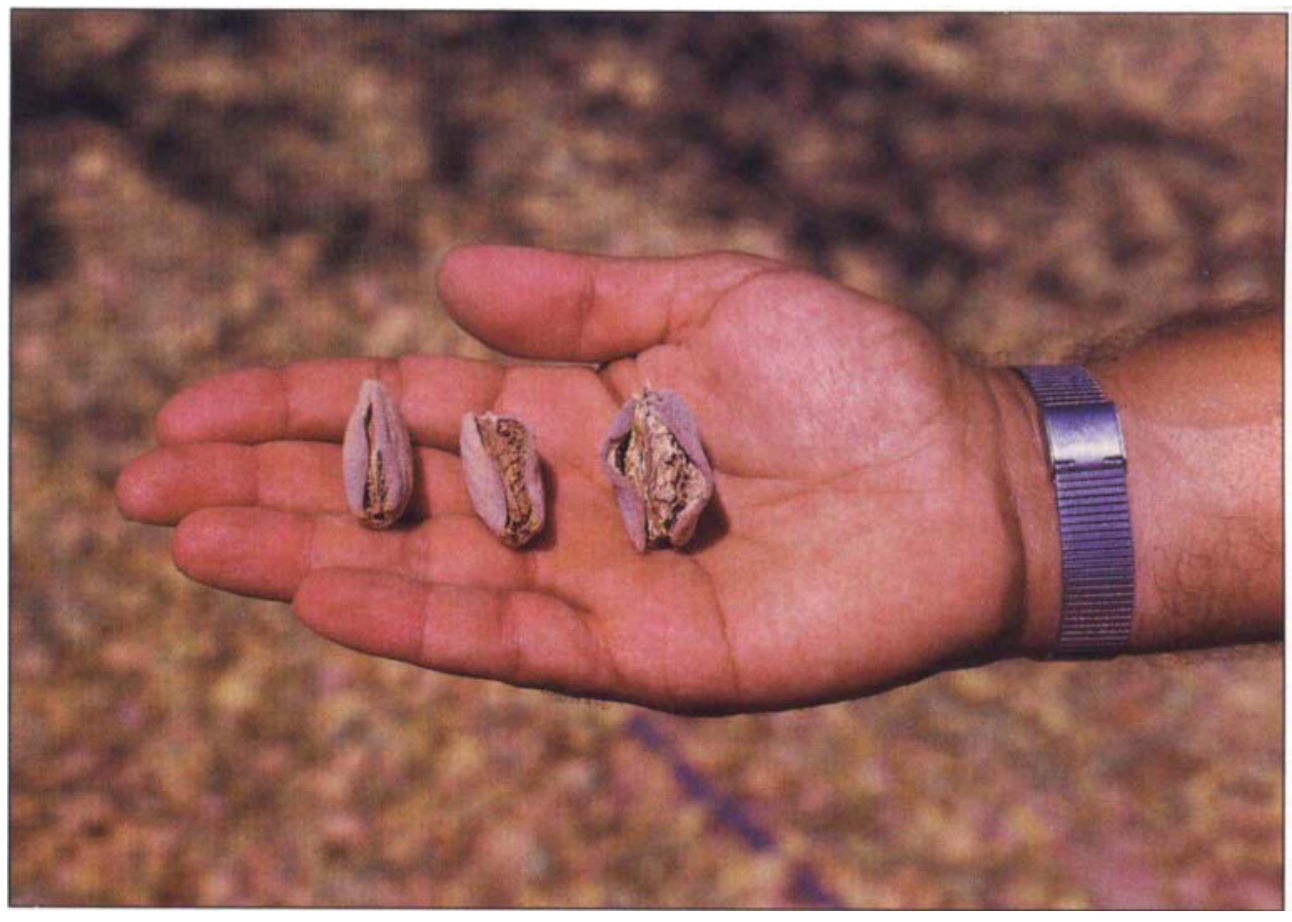

Severe preharvest stress increases hull tight and partial hull split nut production (left and center) at the expense of full split nuts (right).

parameters are usually related under deficit irrigation.

Harvested individual kernel weights were significantly less than the control in all treatments except T5; the greatest decrease occurred in T2, the earliest cutoff (table 3 ). This treatment also had high percentages of par-

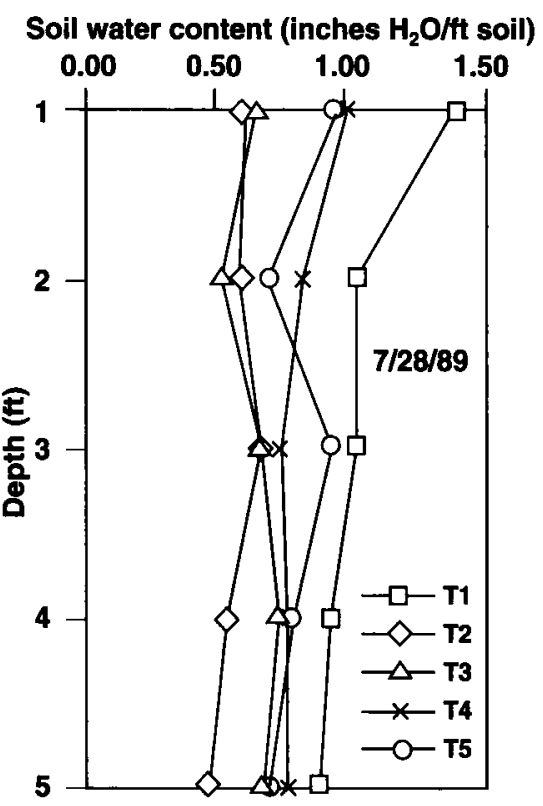

Fig. 2. Distribution of soil moisture just prior to the 1989 harvest after irrigation termination, except for $\mathrm{T} 1$ and $\mathrm{T5}$. tial hull split and hull tight nuts. Reduced hull split can decrease the value of the nuts due to damaged kernels and increased foreign material during processing. Lower individual kernel weights were the primary cause of significantly lower kernel yields in T2 and T3 $(17.6 \%$ and $25.3 \%$ less than the control, respectively); tree nut loads were not significantly different. Individual kernel weight and nut load are the primary yield components in almonds.

Recovery year 1 (1990). Following a return to full irrigation in 1990, production did not return to normal in any of the plots receiving 1989 drought irrigation treatments (table 3 ). Carry-over impacts of the previous year's stress were most severe on nut load. They ranged from a reduction of $62.9 \%$ in 1989 T2 to $9.0 \%$ in $1989 \mathrm{~T} 4$.

This latter value was not significantly different from that of the control. Nut load depends on current season bloom and fruit set. These in turn depend on flower bud development, which takes place during the previous season. In almonds, flower bud development occurs late in the season relative to other deciduous trees. We speculate that severe tree water stress during August and September in $1989 \mathrm{~T} 2$ affected 


\begin{tabular}{|c|c|c|c|c|c|c|c|c|c|}
\hline \multirow[b]{2}{*}{ Year } & \multirow[b]{2}{*}{ Treatment } & \multirow{2}{*}{$\begin{array}{l}\text { Water } \\
\text { applied } \\
\text { through }\end{array}$} & \multirow{2}{*}{$\begin{array}{l}\text { Water } \\
\text { allotment } \\
\text { applied* }\end{array}$} & \multirow{2}{*}{$\begin{array}{l}\text { Total } \\
\text { kernel } \\
\text { yield }\end{array}$} & \multirow{2}{*}{$\begin{array}{l}\text { Individual } \\
\text { kernel } \\
\text { weight }\end{array}$} & \multirow{2}{*}{$\begin{array}{c}\text { Tree } \\
\text { nut } \\
\text { load }\end{array}$} & \multicolumn{3}{|c|}{ Hull splitting } \\
\hline & & & & & & & $\begin{array}{c}\text { Full hull } \\
\text { split }\end{array}$ & $\begin{array}{c}\text { Partial } \\
\text { hull split }\end{array}$ & $\begin{array}{l}\text { Hull } \\
\text { tight }\end{array}$ \\
\hline & & & inches & Ib/acre & gms & $\#$ ftree & (............. & of tree nut $k$ & t........... \\
\hline \multirow[t]{5}{*}{1989} & T1 (Control) & Full season & 40.3 & 1,476 a $\neq$ & $1.24 \mathrm{a}$ & $7,100 \mathrm{a}$ & $98.9 \mathrm{a}$ & $0.4 \mathrm{a}$ & $0.7 \mathrm{a}$ \\
\hline & T2 (Full ETc) † & June 19 & 16.1 & $1,216 \mathrm{~b}$ & $0.97 \mathrm{c}$ & $8,160 \mathrm{a}$ & $38.2 \mathrm{~b}$ & $48.1 \mathrm{~b}$ & $13.7 b$ \\
\hline & T3 (75\% ETc) $\dagger$ & July 11 & 16.2 & $1,103 \mathrm{~b}$ & $1.10 \mathrm{bc}$ & $6,340 \mathrm{a}$ & $85.3 \mathrm{a}$ & $11.4 \mathrm{a}$ & $3.3 \mathrm{a}$ \\
\hline & T4 (50\% ETc) $\dagger$ & Aug 28 & 16.3 & $1,293 \mathrm{ab}$ & $1.03 \mathrm{bc}$ & $7,000 \mathrm{a}$ & $99.0 \mathrm{a}$ & $0.6 \mathrm{a}$ & $0.4 \mathrm{a}$ \\
\hline & T5 (Variable ETc) $†$ & July 31 & 16.0 & $1,480 \mathrm{a}$ & $1.14 \mathrm{ab}$ & $7,670 \mathrm{a}$ & $86.9 \mathrm{a}$ & $11.5 \mathrm{a}$ & $1.6 \mathrm{a}$ \\
\hline \multirow[t]{5}{*}{1990} & $1989 \mathrm{~T} 1$ & Full season & 33.2 & 2,437 a & $1.04 \mathrm{a}$ & $12,850 \mathrm{a}$ & $99.7 \mathrm{a}$ & $0.0 \mathrm{a}$ & $0.3 \mathrm{a}$ \\
\hline & $1989 \mathrm{~T} 2$ & Full season & 32.9 & $813 \mathrm{~d}$ & $1.03 \mathrm{a}$ & $4,770 \mathrm{~d}$ & $99.7 \mathrm{a}$ & $0.1 \mathrm{a}$ & $0.2 \mathrm{a}$ \\
\hline & 1989 T3 & Full season & 32.9 & $1,333 \mathrm{c}$ & $0.99 a b$ & $8,250 \mathrm{c}$ & $99.9 \mathrm{a}$ & $0.0 \mathrm{a}$ & $0.1 \mathrm{a}$ \\
\hline & 1989 T4 & Full season & 33.3 & $1,794 \mathrm{~b}$ & $0.89 \mathrm{~b}$ & $11,690 \mathrm{ab}$ & $99.6 \mathrm{a}$ & $0.0 \mathrm{a}$ & $0.4 \mathrm{a}$ \\
\hline & 1989 T5 & Full season & 32.8 & $1,584 \mathrm{~b}$ & $0.96 \mathrm{ab}$ & $9,080 \mathrm{bc}$ & $99.6 \mathrm{a}$ & $0.1 \mathrm{a}$ & $0.3 \mathrm{a}$ \\
\hline \multirow[t]{5}{*}{1991} & $1989 \mathrm{~T} 1$ & Full season & 33.0 & 2,105 a & $0.97 \mathrm{a}$ & $9,890 \mathrm{a}$ & $98.3 \mathrm{a}$ & $1.3 \mathrm{a}$ & $0.4 \mathrm{a}$ \\
\hline & $1989 \mathrm{~T} 2$ & Full season & 33.0 & $2,077 \mathrm{a}$ & $1.02 \mathrm{a}$ & $9,200 \mathrm{a}$ & $98.8 \mathrm{a}$ & $0.7 \mathrm{a}$ & $0.5 \mathrm{ab}$ \\
\hline & 1989 T3 & Full season & 33.0 & $1,763 \mathrm{~b}$ & $1.02 \mathrm{a}$ & $7,900 \mathrm{~b}$ & $97.9 \mathrm{a}$ & $1.2 \mathrm{a}$ & $0.9 \mathrm{~b}$ \\
\hline & 1989 T4 & Full season & 33.0 & $1,740 \mathrm{~b}$ & $1.13 \mathrm{~b}$ & $7,050 \mathrm{~b}$ & $98.5 \mathrm{a}$ & $1.0 \mathrm{a}$ & $0.5 \mathrm{a}$ \\
\hline & 1989 T5 & Full season & 33.0 & $1,877 \mathrm{ab}$ & $1.07 \mathrm{ab}$ & $7,620 \mathrm{~b}$ & $98.7 \mathrm{a}$ & $0.4 \mathrm{a}$ & $0.9 \mathrm{~b}$ \\
\hline \multicolumn{10}{|c|}{3 Year mean } \\
\hline & $1989 \mathrm{~T} 1$ & & 35.5 & $2,006 \mathrm{a}$ & $1.08 \mathrm{a}$ & $9,948 \mathrm{a}$ & $99.0 \mathrm{a}$ & $0.5 \mathrm{a}$ & $0.5 \mathrm{a}$ \\
\hline & 1989 T2 & & 27.3 & $1,369 \mathrm{c}$ & $1.01 \mathrm{a}$ & $7,378 \mathrm{~b}$ & $78.9 \mathrm{~b}$ & $16.3 \mathrm{~b}$ & $4.8 \mathrm{~b}$ \\
\hline & 1989 T3 & & 27.4 & $1,400 \mathrm{c}$ & $1.04 \mathrm{a}$ & 7,498 b & $94.4 \mathrm{a}$ & $4.2 \mathrm{a}$ & $1.5 \mathrm{a}$ \\
\hline & $1989 \mathrm{~T} 4$ & & 27.5 & $1,609 \mathrm{~b}$ & $1.02 \mathrm{a}$ & $8,581 \mathrm{~b}$ & $99.0 \mathrm{a}$ & $0.5 \mathrm{a}$ & $0.5 \mathrm{a}$ \\
\hline & 1989 T5 & & 27.3 & $1,647 \mathrm{~b}$ & $1.06 \mathrm{a}$ & $8,121 \mathrm{~b}$ & $95.1 \mathrm{a}$ & $4.0 \mathrm{a}$ & $0.9 \mathrm{a}$ \\
\hline
\end{tabular}

some aspect of flower bud development, resulting in lower 1990 fruit loads. Clearly, 1990 fruit load was directly related to the date of 1989 irrigation cutoff; the earlier the cutoff (and presumably the higher the stress in August and September), the lower the 1990 nut load. Note that 1989 T4 included some postharvest irrigation, which we believe enhanced bud development.

Except for 1989 T4, 1990 individual kernel weights were not significantly different from those of the control. We believe that $\mathrm{T} 4$ was lower because 1990 fruit load was the highest of any of the 1989 drought irrigation regimes. Full recovery occurred in hull splitting. Kernel yields paralleled nut load.

Recovery year 2 (1991). Except for 1989 T2, 1991 nut load still had not recovered, averaging about $24 \%$ lower than for the control (table 3). We attribute the relatively high $1989 \mathrm{~T} 2$ nut load to alternate bearing due to the low 1990 level. Individual kernel weights were slightly higher than the control, but generally not significantly so. Kernel yields were significantly lower in 1989 T3 and T4.

Three-year average (1989-1991). Mean kernel yield values after the simulated drought and two subsequent recovery seasons were significantly lower for all drought-year irrigation strategies, but the magnitude of the losses differed greatly between treatments (table 3 ). The kernel yields of 1989 T2 and T3, which applied their 1989 allotment relatively early in the season, were nearly identical and had an average loss of $31.0 \%$. Those for 1989 T4 and T5, which spread out the 1989 irrigation allotment over much more of the season, were also nearly identical, but the yield reduction averaged only $18.9 \%$. We believe this resulted from less tree water stress during the important bud development period in 1989, which enhanced the following season's nut load.

\section{Drought decision making}

The success of a single-season drought irrigation regime must be evaluated based on impacts in both the drought season and subsequent seasons. This is primarily due to carryover effects of the drought-year tree water stress on following years' nut load. The influence of stress timing on individual kernel weight in both the drought season and subsequent seasons is much less. Applying a limited allotment of water early in the season proved less effective in limiting production losses than irrigating at a lower rate but for a longer period of the season. Maintaining good soil (and presumably tree) water status during bud development (August and September) is critical for subsequent bloom and fruit set.

D.A. Goldhamer is Water Management Specialist, Department of Land, Air, and Water Resources, UC Davis, based at the Kearney Agricultural Center, Parlier. T.E. Smith is Agronomist, Britz, Inc., Five Points, CA.

The authors wish to thank Woolf Enterprises, Inc.; Westlands Water District and the California Almond Board for their assistance in this work. 